\title{
Negotiating the foundations of the modern state: the emasculated citizen and the call for a post-patriarchal state at Gezi protests
}

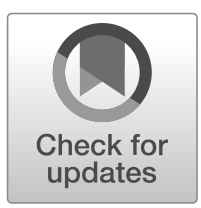

\section{Alev Çınar ${ }^{1}$}

Published online: 29 May 2019

(C) Springer Nature B.V. 2019

\begin{abstract}
Examining Turkey's Gezi Park protests of 2013 as a representative case of the globally surging protest movements since 2011, this study claims that the basic aim of the protests is to contest the foundational rationality of the modern state, which, I argue, is based on a patriarchal social contract that empowers the state with the authority to represent the interests and speak on behalf of citizens using a logic of protection, and to construct, enforce, and monitor a regime of citizenship where citizens can only function as emasculated subjects who are dependent on the protection of the state. Based on an analysis of the use of gender metaphors and familial tropes by the AKP government, and the subversive use of humor and irony by the protestors, this article demonstrates that the protests target the patriarchal premises of modern statehood, both in its democratic (fraternal patriarchy) and authoritarian (paternalistic patriarchy) forms, and the state's disciplinary, regulatory, and remedial interventions toward the interpellation of the citizen as an infantile or feminine subject who is not capable of meeting their needs and interests on their own, and whose life, therefore, needs to be continually monitored, controlled, and regulated by the state. Drawing on criticism brought to the contractual foundations of the modern state by feminist political theorists, this study makes use of the notion of modern patriarchy as a story told by social contract theories, which generates a power relationship between the state and the citizen based on the projection of threat where the state assumes the role of the protector. I conclude that objecting to these modern forms of subjugation, the Gezi Park protests call for a post-patriarchal state where it no longer resorts to a patriarchal protectionist logic that is justified through the claim that it represents the interests of its citizens. By envisioning such a post-patriarchal state, I interpret the protests as a call for the renegotiation of the foundational premises of modern statehood such that the state-citizenship relationship is radically reformulated to enable a more empowered and autonomous citizen.
\end{abstract}

Keywords AKP. Citizenship - Gezi protests - Modern patriarchy $\cdot$ Modern state $\cdot$ Protest movements

Alev Çınar

alevc@bilkent.edu.tr

1 Department of Political Science and Public Administration, Bilkent University, Bilkent, 06800 Ankara, Turkey 
The most famous and influential political story of modern times is found in the writings of the social contract theorists. The story, or conjectural history, tells how a new civil society and a new form of political right is created through an original contract.

(Carole Pateman, The Sexual Contract, 1988, p. 1)

Image 1 shows one of the popular placards at Gezi Park protests, which started on 28 May 2013 in Istanbul as a peaceful rally against the government's plan to demolish Gezi Park, one of the last green areas in central Istanbul, to replace it with a shopping center. When the police responded forcefully to suppress the protests, they not only spiraled into massive nation-wide demonstrations, but also found popular global support from New York, Brazil, and Vienna, to California, London, or Athens. The protests ended in August leaving behind thousands injured and more than twenty deaths, but it soon became clear that nothing would ever be the same again in Turkey.

The placard below states that the people do not need political parties to represent and look out for the needs and interests of different groups in society. This statement seems to point at one of the core impulses of the protests: "we don't want to be represented,

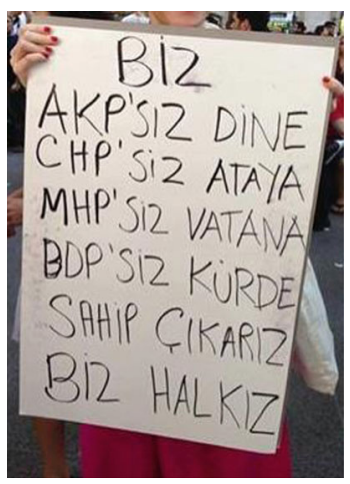

'We will look out for religion without the AKP, for Atatürk without the CHP, for the homeland without the MHP, for the Kurd without the BDP, We are the People'

https://www.sondakika.com/fotogale ri/gezi-parki-eyleminde-dikkatceken-duvar-yazilari/

Image 1 A popular placard at Gezi Park protests 
we don't want to be shepherded, we can take care of our own needs ourselves." The aim of this article is to take a closer look at the slogans, graffiti, and other forms of expression at Gezi Park protests to understand what is meant by representation here, explore what exactly is being protested, and elaborate on the consequences of the objection to representation of interest on the foundational rationality of the modern state, which establishes its governmental authority and its right to rule on the claim that it represents the interests of the people. The protests primarily targeted the political language, attitude, and approach of the state toward its citizens in general, which not only included the then prime minister Recep Tayyip Erdoğan and the AKP, ${ }^{1}$ but also other political parties, leaders, and whomever else assumed the voice of the state to justify regulatory interventions into the lives of citizens. As one of the protestors, who was the first to stand in front of the bulldozer to stop it from demolishing the park observed, the main statement that Gezi protestors are making is: "you cannot tell me what I can wear, eat, drink or how I can reproduce," "you cannot regulate my life." (Önder 2013) This article seeks to demonstrate that the objection to such interventions expressed by the protestors goes beyond any particular political party, leader, political institution, the government, or representative democracy as a regime type, but targets the general idea of representation of interest that is one of the core constitutive principles of the modern state.

Similar protests that have swept across the world since 2011 suggest that the objection to the principle of representation of interest is not unique to Turkey but is a common element in protests all over the world. Protestors similarly chanted "you cannot represent us" in Russia; "you don't represent us" in Spain; "the government does not represent the people" in Portland, Maine; "no party represents me" in Brazil; and similar slogans were chanted in protests from Israel, Egypt, and Slovenia, to Tunisia, the United Kingdom, or Greece. Even though each of these protests rose out of local issues that are unique to the country in which they erupted, they all rallied around the same objection raised against the government's claim to represent them. Examining the common slogans emerging in protests in over a dozen countries, Azzellini and Sitrin note that "The slogans are not phrased as rejections of specific political representatives, but as expressions of a general rejection of the logic of representation. The "representation of interests" does not work. It is perceived as undemocratic; people mobilizing do not feel "represented," and they no longer believe that "representation" by those in power is possible" (Azzellini and Sitrin 2014, p. 41).

Like protest movements in other countries, Gezi has attributes that are unique to Turkey, and parts of the demonstrations no doubt directly targeted the Turkish government and Erdoğan. However, what makes Gezi stand out among different protest movements in Turkish history is the lack of political references that target a specific political ideology, party, or movement, or address a particular issue on Turkey's immediate political agenda. Instead, Gezi slogans and graffiti predominantly used a non-political, non-ideological, cosmopolitan language (see Image 2) that made references from the Game of Thrones to Guy Fawkes and Anonymous, from the Hobbits to Bob Marley, from Jamiroquai

\footnotetext{
${ }^{1}$ The AKP (Justice and Development Party) was founded under the leadership of Recep Tayyip Erdoğan in 2001 after its predecessor was closed by the Constitutional Court for activities against the "Laicism" clause of the Turkish Constitution. The AKP came to power in 2002 and has won every election after that often receiving close to $50 \% \%$ of the vote. In 2014 Erdoğan became the President after Turkey's first Presidential election.
} 


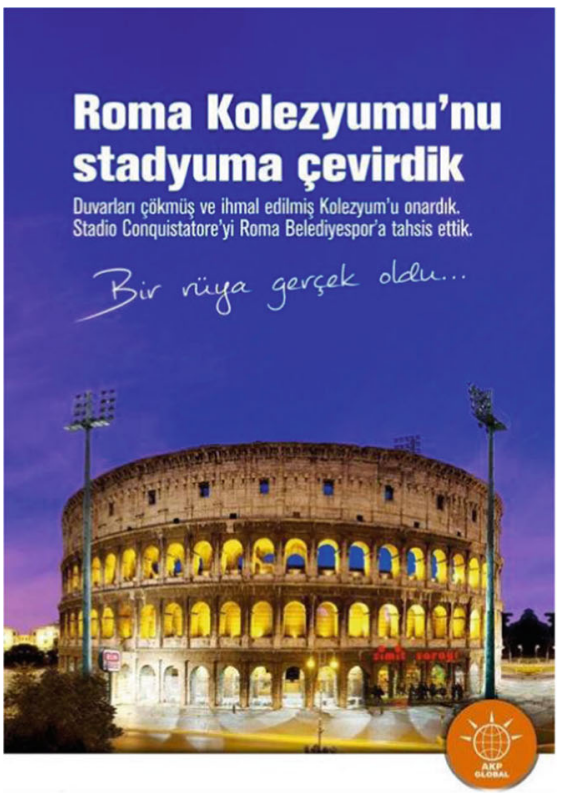

"AKP Global: We transformed the Coliseum into a stadium. We repaired the torn down and neglected Coliseum. We allocated the Stadio Conquistatore to the Rome Municipal sports team. A dream has been realized..."

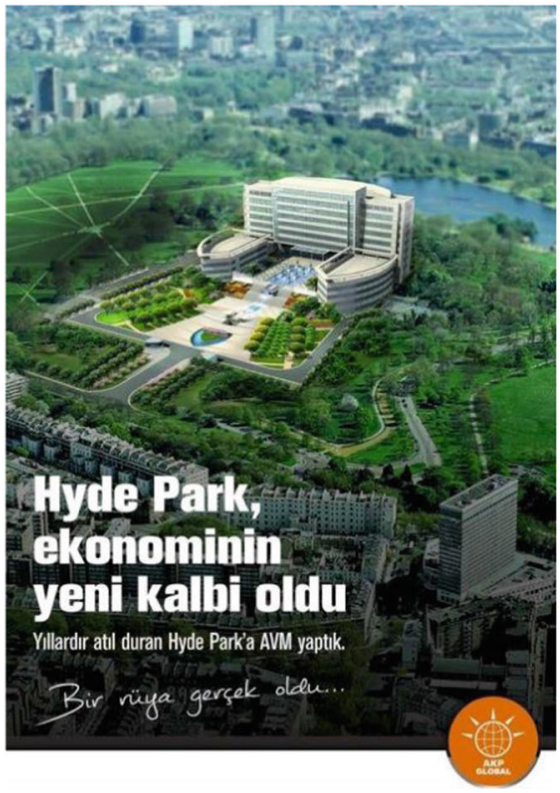

"AKP Global: Hyde Park became the new heart of the economy. We built a mall in Hyde Park that has been idle for years. $A$ dream has been realized..."

Image 2 Mock AKP campaign posters circulating in the social media during Gezi that illustrate the remedial interventionism of the AKP, and the non-political, no-agenda, cosmopolitan approach to protest. "Sosyal medyada 'AKP dünyayı yönetseydi ne olurdu' esprisi. [Social Media Humor: 'What would happen if the AKP ruled the world']” t24.com.tr, July 12, 2013. http://t24.com.tr/galeri/akp-dunyayi-yonetirse/3965

("jamiryo") to various internationally famous soccer players, and use of English phrases and words intentionally misspelled and combined with Turkish words as a display of the globality of the main motives of the demonstrations (see Image 3). Humor was the common element that brought together diverse forms of expression, which not only allowed people and groups with very different backgrounds and political opinions to come together, but also boosted the countrywide and global popularity of the protests.

This article aims to show that the Gezi Park protests gained global attention and have resonated with similar protest movements across the world because they targeted not only the authoritarian governmental practices of the AKP government, but more importantly, the logic of representation of interest, which is, as discussed here, one of the key foundational principles of the modern state both in its authoritarian and democratic forms, and the types of citizenship that the state produces to justify its power and authority using this logic. Drawing on criticism brought to the modern liberal state by feminist political theorists such as Carol Pateman, Iris Marion Young, and Wendy Brown, this article makes use of the notion of modern patriarchy as a story told by social contract theories, which generates a power relationship between the state and the citizen based on the projection of threat where the state assumes the role of the protector. The story of the social contract places the state and the citizen in a patriarchal 


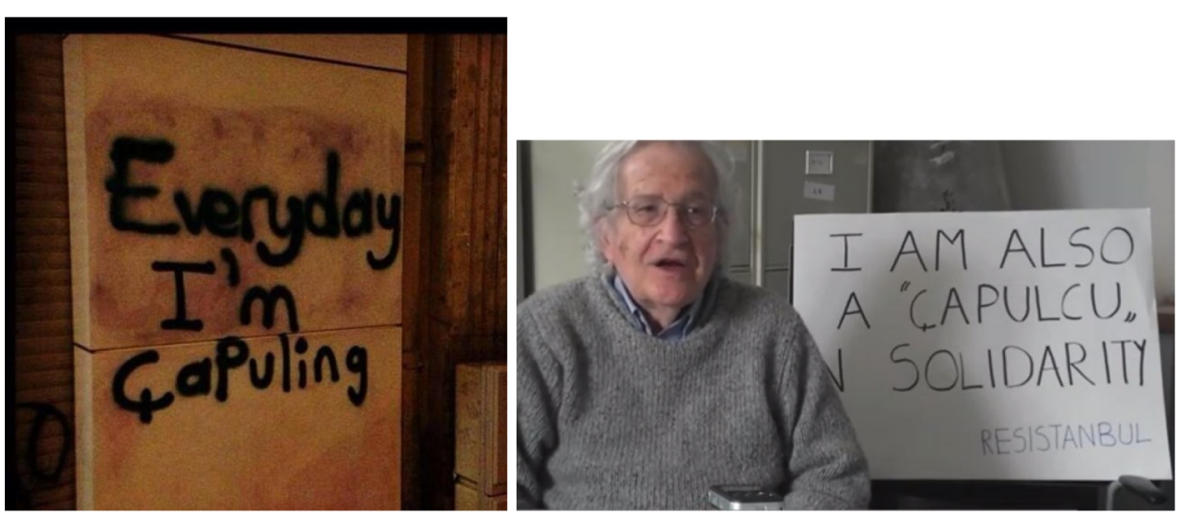

Image 3 "Everyday I'm Çapuling" became one of the most popular slogans of the protests. Among many others, Noam Chomsky also adopted the word "Çapulcu" to show support for the Gezi protests. (https://en. wikipedia.org/wiki/Chapulling); http://bianet.org/bianet/insan-haklari/147248-chomsky-de-capulcu

relationship either as father-children (authoritarian/paternalistic patriarchy), or as husband-wife or brother-sister (democratic/fraternal patriarchy). It follows that each mode of patriarchy interpellates a specific model of citizenship: authoritarian patriarchy produces the "infantile citizen" who is not capable of rational decision making and whose existence depends on protection by the father/state; and democratic patriarchy produces seemingly a less hierarchical, more egalitarian understanding of citizen-aswife, mother, or sister, whose femininity represents another form of emasculated citizen whose needs and interests can only be met by the state. Both modes of patriarchal statehood interpellate the citizen as an emasculated subject who is not capable of meeting their needs and interests on their own, and whose life, therefore, needs to be continually monitored, controlled, and regulated by the state. I discuss that this logic of representation of interest, which is a fundamental feature of the modern patriarchal state inherent in social contract theory, operates continually at different levels of governance and statehood to establish and legitimize the authority and power of the state through the claim that it is acting in the best interests of the citizens and is the protector of their lives, safety, and wellbeing. This study demonstrates that the AKP government under Erdoğan frequently employs this logic in addressing citizens either as children who are in need of the protection and parental guidance as part of paternalistic type of patriarchy, or as feminized subjects (wives, mothers, or sisters) whose wellbeing and integrity can only be secured by the protection provided by the state. I argue that it is this logic of representation of interest, which is used to justify not only oppressive (authoritarian), but also regulatory and remedial (democratic) interventions emanating primarily from fraternal/democratic forms of patriarchal governance that was the main target of the Gezi Park protests and that the protestors targeted this patriarchal subjection of citizens to tightly tailored models of citizenship that reduce them to emasculated generic subjects who are always in need of protection, guidance, and supervision. Based on an analysis of the addresses of the AKP government and Erdoğan, and the humorous ways in which these were protested, this article concludes that the goal of the protests is to call for a post-patriarchal state where it no longer assumes the role of the protector and does not assign citizens tightly regulated, constraining roles that only allow them to speak through a voice of victimhood. 


\section{Gezi Park protests}

The widespread protests that started on 28 May 2013 as a peaceful sit-in against the demolition of the Gezi Park and the plans to turn it into a shopping mall became not only one of the most significant landmarks in Turkish politics, but also one of the significant links in the chain of similar protests that have swept across the world since 2011. Gezi Park protests were exceptional in terms of the diversity of the participants, the widespread and effective usage of social media, its creative and humorous slogans, and its wide spectrum of activities ranging from public forums to planting of flowers, from street performances to the painting of boardwalks and stairs. ${ }^{2}$ One of the most unique features of the protests was the use of the Gezi Park as a communal living space where protestors set up tents; nearby restaurants and voluntary groups put up food stands and distributed free food; participants set up a mobile library and gathered together around reading groups, playing music, doing communal art, or planting flower gardens; doctors, lawyers, nurses, and even veterinarians offered their services for free; some shops and businesses volunteered to provide electricity, water, and even portable toilets to pitch in. But perhaps the most significant feature of Gezi protests was the ways in which individuals from different backgrounds, ideological affiliations, and identities - ranging from anti-capitalist Muslims, secularists, Islamists, Kurdish and Turkish nationalists, and Marxists, to Alevis, environmentalists, LGBT activists, workers' unions, students, football fans, new age groups, and members of nonMuslim and non-Turkish communities - came together to protest the government's policy side by side. When the police intervened forcefully with tear gas and pressurized water to remove the tents and disperse the protests, the target shifted from the demolition of the park to the Turkish government and particularly the leadership of Erdoğan. Suddenly, placards and graffiti spread throughout the park expanding into the adjacent Taksim Square, and then into other towns and cities across Turkey. Protests targeted the police and Erdoğan but never addressed a specific ideology, policy, or a political party and largely remained nonviolent using humor as the common subversive weapon. Graffiti such as "dear brother police officer, you are bringing tears to my eyes," "we are being gassed up," "you look very pretty when you are angry my country," "pepper spray is good for your skin," "OMG is this a revolution?" or "Winter is coming Tayyip" rapidly spread not only on walls and placards all over Turkey but also the social media.

By August, the protests were forcefully put down by the police resulting in the death of at least a dozen civilians and thousands injured; the ruling AKP had framed the protests as a "civilian coup attempt" against Erdoğan"; and Erdoğan had declared the protestors as "terrorists" (CNN Türk 2014). Even though the protesters were deemed to have been defeated by the government, it was clear that Gezi had already become a historical milestone. Many scholars suggest that the Gezi protests mark a new threshold for Turkish democracy (Acemoğlu 2013; Göle 2013) wherein the foundations of old style political practice have been challenged, paving the way for a "new" politics.

\footnotetext{
${ }^{2}$ For studies on Gezi see, for instance, (Aytaç et al. 2017; Bakıner 2014; Damar 2016; Göksel and Tekdemir 2018; Göle 2013; Konak and Dönmez 2015; Özen 2015; Stewart et al. 2019; Taș 2017; Tuğal 2013; Whitehead and Bozoğlu 2016; Yörük and Yüksel 2014).

${ }^{3}$ The AKP Executive Board met on 9 June 2013 to discuss the Gezi Park incident and later made a statement to the media that the protests were part of an internationally supported civilian coup attempt (Șahan 2013).
} 
As the dust - and the teargas - cleared from the squares, it became evident that Gezi had become a global phenomenon. As Gezi protests were unfolding, various different rallies and demonstrations were held in support all over the world. One of the most popular slogans of the protests, "Everywhere is Taksim, resistance everywhere," was being chanted all over the world - through a flash mob drum performance in Vienna, a 5 K run in California, a "Chapulcu's Horon Dance" gathering in Germany, a "standing man" protest in Belgium, and other similar creative forms of protest from Brazil to Denmark, from Spain to New York. ${ }^{4}$

This study explores the way in which the AKP government and Erdoğan consistently resorted to gender metaphors and familial tropes emanating from the patriarchal social contract story in the construction and justification of its authority and power, its interpellation of a type of citizen that is emasculated through infantilization or feminization, and how the main objection of the Gezi Park protests was this ongoing emasculation of the citizens by the state. It seeks to demonstrate how a government can resort to different sorts of patriarchal claims of increased need for protection of its citizens to justify both authoritarian measures that bring limitations to rights and freedoms, as well as regulative measures typical of democratic regimes that seek to remedy and shepherd the lives of citizens; and how these attempts were resisted and subverted in ways that challenge the patriarchal foundations of the modern state.

\section{Stories of patriarchy and the masculinization of the state}

The main premise of this article is that the state's claim to the representation of interests, which is the main target of the Gezi protests, stems from the patriarchal foundations of the modern state and its corresponding modes of citizenship. Drawing on a critical reading of social contract theory by feminist political theorists, I argue that the modern state, both in its authoritarian and democratic forms, justifies its authority and power based on the claim that it represents the best interests of its citizens, which are defined as the need for protection, safety, and peace, and that it alone has the capability and power to provide these. In return, the state demands citizens to accept the citizenship model that it assigns them, which portrays the citizen as a subject who willingly accepts this role, recognizes and accepts the authority of the state, and abides by its laws. I further argue that this model interpellates the citizen as an emasculated subject, who lacks the power and autonomy to tend to its own needs and interests, and that the main target of the protests is this emasculation of the citizen by the patriarchal state.

Social contract theory is predominantly dealt with under political philosophy as a normative framework that provides the norms and principles upon which the modern state is founded and its authority is legitimized. In her critical reading of the social contract, Carole Pateman qualifies social contract theory as "the most famous and influential political story of modern times," (1988. p. 1) thereby engaging it not as a contract but as a story, which shifts the terms of the debate away from a discussion on

\footnotetext{
4 “Gezi Solidarity Videos.” Everywhere Taksim. http://everywheretaksim.net/tag/gezi-solidarity-videos-2/ . 21 July 2013; "Kırmızılı Kadın Brezilya'da!” Radikal, http://www.radikal.com.tr/dunya/kirmizili_kadin_ brezilyada-1141510/. Retrieved 13 May 2017. See different country cases covered at http://www. globaluprisings.org/Retrieved 13 May 2017; see also, (Ezbawy 2012; Mercea and Bastos 2016).
} 
who agrees to what with whom and why, to a discussion on the kinds of relationships, hierarchies, and subjectivities narratively formed through the story of the contract. According to Pateman, the social contract, which is basically a story about "the exchange of obedience for protection," not only creates citizenship by transforming individuals into citizens, but also establishes the state as the superior party to the contract "who provides protection," and in return, assumes "the right to determine how the other will act to fulfill their side of the exchange" (1988, pp. 58-59) In Pateman's account, the social contract is a story that lays the foundations of the modern, liberal state, which replaces the traditional monarchical state when "the father is (metaphorically) killed by his sons, who transform (the paternal dimension of) the father's patriarchal right into civil government" (1988, p. 32). Contrary to the claim contract theorists make about the abolishment of patriarchy through the social contract, Pateman argues that while the modern state was made possible by the toppling of the king-father, thereby ending the reign of traditional/paternal patriarchy and replacing it with the reign of equal, free men, patriarchal foundations of the state remained intact in the form of fraternal patriarchy where the domination of women by men has continued in the separation of the public and the private spheres, and has been institutionalized in modern civil society and citizenship (1988, p. 3).

For the purposes of this article, what is significant in Pateman's account is that her critical reading of the social contract not only overturns the claims of liberalism in bringing equality and freedom to all of society, but more importantly reveals that the modern state is founded upon and sustained by hierarchies and power relations that it had claimed to have ended. If this is so, then we need to take a closer look at the ways in which modern democracies operate to produce hierarchies and engage in new forms of domination and subjugation behind the guise of liberty and egalitarianism. This study seeks to demonstrate that the main impetus behind the Gezi Park protests is to object to these modern forms of subjugation that the state engages in toward the construction, supervision, and enforcement of a model of citizenship that serves to establish, sustain, and legitimate its authority.

At first sight, Pateman's framing of social contract theory as being covertly patriarchal may seem to be based on a notion of patriarchy that is defined as the subordination of women by men. But if patriarchy, in its fraternal form, is understood as a feature of "the modern, liberal form of politics" (Dean 1992, p. 126) then the debate on patriarchy and feminist criticism of the modern state needs to shift its focus away from what men do to women, to the ways in which masculinity and femininity function as metaphors in the construction of power and authority. Even though Pateman herself defines patriarchy as "men's domination over women" (1988, p. 2), which is how the term is predominantly defined in feminist theory, a closer look at her work reveals that the concept of patriarchy she uses is not defined in terms of power relations between actual men and women but is rather seen as a story that generates these and other power relations through the use of gendered and familial metaphors. Referring to this as a "deconstructivist approach" to social contract theory, Diane Coole suggests to focus on "the gendered nature of the representational system itself" where masculinity and femininity operate as metaphors that are used to create hierarchies and power relations, regardless of whether the participants of these relations are men or women. Coole stresses that "social contract theory might be deploying certain gendered oppositions which continue to operate [...] even if women are included as equal citizens" (2003, p. 200). 
In her attempt to define what masculinist power may mean independent of men's domination of women, Wendy Brown similarly notes that "the state can be masculinist without intentionally or overtly pursuing the 'interests' of men precisely because the multiple dimensions of socially constructed masculinity have historically shaped the multiple modes of power circulating through the domain called the state" (1992, p. 14).

In its assessment of the ways in which the AKP government resorts to patriarchal narratives toward the establishment and legitimation of its power and authority, this article adopts this approach and defines patriarchy, not as women's subordination by men, but instead as a story whereby femininity and masculinity are narratively constructed and positioned in a hierarchical relation to one another in a way that generates, sustains, justifies, and legitimizes power and authority, independently from what men do to women. It is this conceptualization of patriarchy as a narrative tool with which gendered subjectivities and hierarchies are constructed that is used in this study as the basis to the claim that the modern state is fundamentally and inherently patriarchal. It is not patriarchal because it enables men to dominate women, but because it establishes its supremacy by taking on a masculine role and assigning to people under its dominion a feminine or infantile status in ways that serves to justify its existence and legitimize its authority. This feature of modern statehood is demonstrated in the abundance of familial and gender metaphors used by political leaders under all sorts of regimes and governments around the world. ${ }^{5}$ Studies on the use of gender and family tropes in relation to politics, authority and nation-building in Turkey have explored the use of women's images in the construction of a modern, secular national identity during the founding years (Arat 1997; Baydar 2002; Çınar 2005, 2008; Sancar 2012; Yeğenoğlu 1998); examined how family tropes have been instrumental in the construction of nationhood and citizenship (Kandiyoti 2001; Kaya 2015; Sirman 2005); or the use masculinity as a trope of power, political authority, and military might (Akyüz 2012; Altınay 2004; Çiçekoğlu 2019; Çınar and Üsterci 2009; Sancar 2016). Erdoğan's rule is no exception. As illustrated below, Erdoğan's speeches are replete with gendered and familial metaphors where he refers to citizens as "my sisters" or "our daughters," addresses the nation as a beloved woman, and even refers to past governments as "patriarch" or "father" in a negative way so as to distance himself from the oppressive and domineering connotations of these terms. Such rhetoric, which feminizes the citizen by marking her as a sister, mother, or daughter, is a critical aspect of fraternal/ egalitarian patriarchal forms of governance, where the state drives its power and authority from the feminization of the citizen whose wellbeing, safety, or integrity are at stake unless the state assumes the role of the masculine, able protector, and steps in to look out for the interests and needs of its emasculated citizens.

\section{Logic of protectionism and two types of patriarchal governance}

At the conceptual center of all these accounts of patriarchy, the social contract, the modern state, and the representation of interest sits the notion of protectionism, which operates as an ordering principle that lays the foundation of modern political systems.

\footnotetext{
5 See, for example, (Johnson 2010; Lauenstein et al. 2015; Mayer 1999; Mostov 1999; Schatzberg 2001; Thomas 2011; Verdery 1994; Wedeen 2015; Zacharias 2001)
} 
Patriarchy as a narratively constructed system of gender-based hierarchies operates through discourses of the family and invariably makes use of familial relations and metaphors set around protection as a core constitutive concept. In her account of the ways in which patriarchy is "deeply embedded in, and reproductive of, the masculine narrative and the discourses of protection," Terry Threadgold notes that "the story of the family is of a masculine parental hero (protector) who defends and protects those within his power (care) from those who might harm them" (1994, p. 17).

Read as a patriarchal story as such, the social contract defines a similar situation where people in the state of nature, or under circumstances where there is no state, are projected as being under threat and in need of a protector. Individuals in the state of nature are invoked as subjects whose prime interests boil down to a need for protection that can only be met by a centralized, singular administrative body, the state. In the hands of the state, such stories of patriarchy become the main mechanism with which it establishes itself as the protector (by assuming the role of the father, husband, or brother) of the nation, which is often invoked as wives, sisters, mothers, or children who are to be protected against a projected threat (of anarchy, chaos, death, destruction, subjugation, immorality, or injustice). In this light, social contract theory can be read as a story that establishes the state as the only viable provider of protection, just as stories of patriarchy project the male head of the family as the able protector who is needed for the survival and wellbeing of women and children. Emphasizing that paternalist protectionism is an inherent part of the social contract, Wendy Brown notes that "within liberalism, paternalism and institutionalized protection are interdependent parts of the heritage of social contract theory in which 'natural liberty' is traded for the individual and collective security ostensibly guaranteed by the state" (1992, p. 8). Writing along the same lines, Iris Marion Young posits that "the gendered logic of the masculine role of protector" becomes the key principle upon which the modern state is founded. She draws attention to the parallel between the patriarchal head of the household and the head of the state, and she notes that "in this patriarchal logic," the state "puts those protected, paradigmatically women and children, in a subordinate position of dependence and obedience" (2003, p. 2). In other words, based on the logic of protection that operates through the social contract, the state legitimizes its existence and authority by portraying itself as the ultimate protector of the lives, safety, and well-being of all whose interests it claims to represent.

It might be necessary at this point to clarify the difference between paternalistic and fraternal types of patriarchy, both of which are used frequently by feminist theorists in referring to the modern, liberal state. Even though protectionism is associated with "a more authoritarian and paternalistic state power, which gets its support partly from the unity a threat produces and our gratitude for protection" (Young 2003, p. 3), Pateman and others posit that the logic of protectionism operates the same way in fraternal forms of patriarchy as well, which constitutes the foundational rationality of the modern, liberal state (1988, p. 7). Wendy Brown elaborates on fraternal stories of patriarchy that are evoked by democratic regimes and leaders when she talks about "the politics of protection and regulation" as it emerged gradually since the nineteenth century in the United States through "campaigns for suffrage, protective labor legislation, temperance, birth control, and marriage law reform. In the twentieth century," she notes, "the list expanded to campaigns for equal opportunity, equal pay, equal rights, and comparable worth; reproductive rights and public daycare; reform of rape, abuse, marriage, and 
harassment laws" (1992, pp. 7-8) These accounts suggest that while claims to protection from threat, anarchy, and war are used to justify authoritarian governmental practices, the protection of rights, liberties, morality, or welfare is used by democratic governments to justify regulatory or remedial interventions. The first type of patriarchy is of the paternalistic kind, where the government often assumes the voice of a benevolent father who is willing to take any measures necessary to protect his children, whereas the second type is of the fraternal kind, where political leaders assume the role of the husband or brother who is there to take all kinds of regulatory and remedial interventions toward the protection of the wellbeing and welfare of his wife (as the mother of his children) or sisters. Despite the differences, in both types of patriarchy, the logic of protection is equally at work, and both authoritarian and democratic governmental practices are equally justified through the representation of interest, which is defined by the state as the need for protection. Instead of framing particular governments or regimes as being solely one type of patriarchy or the other, this study works with the assumption that both the paternal/authoritarian and the fraternal/ egalitarian type of patriarchy can be utilized by the same government depending on circumstance.

In their study of the AKP government's gender policies, Coșar and Yeğenoğlu make a similar observation about the ways in which the AKP embodies both authoritarian and liberal types of patriarchy. Coșar and Yeğenoğlu discuss how the AKP regime is a fusion of republican, religious, and liberal modes under what they refer to as "neoliberal-conservative patriarchy" (2011, p. 560) Their discussion points to at least two different types of patriarchy: while republican patriarchy is a classical type of patriarchal governance that is paternalistic and authoritarian, what they refer to as the "liberal mode of patriarchy" is about the liberation of women in favor of full participation in the public sphere- but which, the authors argue, is nevertheless patriarchal, because it is the state that orchestrates this liberation and enables women's participation, but remains as the ultimate authority that controls who and in what conditions can be included in the public sphere. ${ }^{6}$

This study works with the same understanding of the liberal form of patriarchal governance, except that instead of basing the notion of patriarchy on policies toward women, it bases it on how the state defines, interpellates, manages, and shepherds all citizens by resorting to familial narratives and patriarchal modes of power. I maintain that it is this rationality of the liberal form of governance that empowers the state to intervene in and regulate the lives of citizens through the monitoring and controlling of the conditions of inclusion in the public sphere, which is justified by the state's claim to represent the common good, the general will, or the best interests of citizens. It is this logic of representation of interest that the liberal mode of patriarchal governance is based upon and is protested at Gezi. As demonstrated below, while the AKP government increasingly resorted to authoritarian measures after the Gezi protests, it is particularly the regulatory, remedial interventionism of the modern democratic state that was the main target during the Gezi protests.

\footnotetext{
$\overline{{ }^{6}}$ For more on women's controlled inclusion in the public sphere as a means of generating political power, see (Çınar 2008).
} 


\section{Feminization, infantilization, and the emasculated citizen}

There is another side to the story of the social contract: The citizen. The logic of patriarchal protection works only if there are individuals that the state can claim to be in need of protection. In other words, for this mechanism to work, it is not only that the state continually needs to establish itself as capable of providing protection to the citizens, but also create and project an image of citizen as in constant need of guidance and protection from threats. For this dual projection of state-as-protector and the citizen-as-protectee to work, it needs to be accompanied by the continual projection of threat. This continuous interpellation of the state and the citizen through narratives of threat and patriarchal protection lies at the foundations of the modern state, in its authoritarian and democratic forms alike.

Read as a performative story, the social contract can be interpreted as an agreement between the state and the citizen, who come into being the moment it is performed (Butler 1990, p. 278). The performance of the contract takes place when the state "hails," or interpellates the citizen through its laws and law enforcement and the citizen recognizes the authority of the state by responding to the summons (Althusser 2014, pp. 190-191; Butler 1997). The ongoing interpellation of the citizen by the state becomes the performative act through which statehood and citizenship are mutually constructed, neither of which exist prior to the contract. This study draws on the Althusserian notion of interpellation through the hailing of the citizen by law enforcement, but locates the point of interpellation not in the actual moment of hailing, or even the writing of laws prior to their enforcement, but rather in the story of the social contract that creates subject positions for the state and the citizen, and places them in a hierarchical relationship, making it possible for the state to codify the contract, enforce the law, and hail the citizen.

This understanding of citizenship is articulated by Leti Volpp in her study of the creation of a new identity category in the post-9/11 period, namely the Arab or the Muslim terrorist, who were "disidentified as citizens" (2002, p. 562) through what she refers to as "a process of interpellation" (2002, p. 578). Drawing on the works of Althusser and Butler, Volpp notes that "citizenship as a process of interpellation starts from the perspective that power both subordinates and constitutes one as a subject" (Volpp 2002, p. 578). In her study of the experiences of refugee Somali women in France in terms of their access to citizenship and public recognition, Leah Bassel similarly discusses how the citizen is interpellated as a subject who fits with the models envisioned for it by the state. Bassel notes that the state interpellates Somalian Muslim women as citizens by imposing on them "a hierarchy of needs" and using a "language of protection"(2008, p. 304), which constitutes them as subjects “'deserving' of public recognition and support" (p. 313) and protection from "oppression by their men" (p. 304). According to Bassel, in the "hiearachy of needs" defined by the state, protection is at the top, which is used in the interpellation of citizenship in ways that allows the state to shape the terms of public debate and control the inclusion and exclusion of subjects. The need for protection that the French state imposes on citizens is quite similar to the logic of representation of interest that this study takes as the main target of the Gezi Park protests. In both cases, the state justifies its power and authority by interpellating a model of citizenship based on the claim that it represents the interests of citizens, which it defines as the need for protection and guidance. 
As these examples demonstrate, the patriarchal rationality of modern statehood assigns not only the state a masculine role as protector, but also the citizen a feminine or infantilized role as the potential victim in need of protection. Assuming the role of the father, authoritarian/paternalist modes of statehood often address the citizen as an infant who is not capable of rational decision making and whose existence depends on protection by the father-state. Whereas democratic/fraternal modes of patriarchal governance project the citizen as wife, mother, or sister, whose needs and interests can only be met by the husband- or the brother-state. In either case, both modes of modern statehood operate with the logic of patriarchal protection to interpellate the citizen as an emasculated subject either through intfantilization or feminization.

The relation between gender and citizenship in Turkey has been widely examined by studies that explore how women have been implicated in ongoing state, nation, and citizenship building efforts as part of modernizationist policies during the founding years, as well as neoliberal governmental practices under the AKP, the majority of which address the issue in terms of women's subjugation by the state. Examining the ways in which governments have been actively involved in the regulation of women's lives, bodies, or images, these studies focus either on women's confinement to the private sphere (Baydar 2002; Dönmez and Özmen 2013; Sirman 2005), their controlled inclusion in the public sphere as mothers to act as producers of future generations and soldiers who will protect the nation (Korkman 2015; White 2003; Yeğenoğlu 1998), or their conditional inclusion as defeminized, desexualized subjects (Gökarıksel 2009; Göle 1996; Kandiyoti 1997; Parla 2001). ${ }^{7}$ This study contributes to this debate by approaching the state's citizenship building efforts, not in terms of the subjugation of women, but as the use of feminization (and infantilization) as discursive techniques toward the interpellation of citizens as emasculated subjects at the expense of the individual autonomy of both men and women. This study demonstrates that Gezi Park protestors targeted this patriarchal subjection of citizens to a tightly defined model of citizenship, which reduces them to emasculated generic subjects that can only speak through a voice assigned to them by the state.

\section{The AKP's patriarchy and Gezi protests}

The image of the state as a father figure who protects, provides for, and shepherds its infantilized citizens has a long and uninterrupted history in the Turkish case. As Șerif Mardin has demonstrated, the Turkish state has maintained its domineering power over the periphery and it has seen itself as the top-down (read paternal) modernizer and bearer of wisdom (1973). Many of Turkey's former political leaders and particularly those in the conservative camp, such as Süleyman Demirel, have exploited the image of the benevolent father $(b a b a)$ to consolidate and legitimize their authoritarian interventions and top-down hardliner stances (Akyüz 2012, p. 113). But alongside this paternalistic streak, fraternal type of patriarchal statehood that produced images of the state

\footnotetext{
${ }^{7}$ Other similar studies include (Arat 2000; Ataman 2011; Baydar 2002; Kadığlu 1998).
} 
as a populist, egalitarian brother also played a significant role in Turkey's political history starting with the founder of the modern republic, Mustafa Kemal himself, who frequently addressed the public as friends or brothers in his speeches (Bozk1r 2010; Çinar 2010, p. 98). But the ultimate symbol of fraternal patriarchy in Turkish politics is Demirel's social-democrat counterpart, Bülent Ecevit, who was given the nickname "Karaoğlan," named after the popular folk figure that depicts a young, selfless man who fights to bring justice to his people (Akyüz 2012, p. 115; Çolak 2017, p.165). Turkish politics is full of such references to patriarchal masculinities that are used to establish and legitimize the power and authority of the state to monitor and regulate the lives of its citizens by assuming the position of the protective benevolent father, husband, or brother, and interpellate the citizen as a vulnerable, defenseless child, an imprudent teenager in need of parental guidance, a wife whose motherhood depends on the presence of a strong, providing, protective husband, or a sexually vulnerable younger sister whose protection from offenders becomes the ultimate measure of the power, authority, and honor of the state. ${ }^{8}$ In this political rhetoric, authoritarian modes infantilize citizens, whereas democratic forms feminize them, but both interpellate the citizen as an emasculated subject who needs the protection of the state.

As discussed earlier, AKP's governmental practices present a novel case where it brings together authoritarian/paternalistic with democratic/fraternal types of patriarchal statehood into what has been termed "neoliberal-conservative patriarchy" (Coşar and Yeğenoğlu 2011, p. 560). This assessment is confirmed by this study, where Erdoğan's addresses demonstrate that the AKP assumes both the voice of the benevolent father, and of the justice-seeking egalitarian brother to justify tutelary, regulatory, or remedial interventions that seek to control, shepherd, and modify the lives of citizens.

The AKP has been considered a conservative democratic government during its first two terms (Dağ 1 2008; Hale 2005). After its third term in power starting in 2011, the party took on an increasingly authoritarian stance, taking harsher measures against the opposition, increasing its control over the media, adopting a more overt Islamic identity, and displaying intolerance toward criticism (Çınar 2018; Esen and Gümüşçü 2016) This authoritarian turn was accompanied by an escalation in Erdoğan's adoption of a paternalistic voice in addressing citizens. In a statement about the AKP's renewed vision in its third term, Erdoğan said that their goal was to raise "a new pious youth, [...] a new conservative and democratic generation that honors the values and historical ideals of its nation." Soon after these declarations, the AKP went on to ban the sale and consumption of alcoholic beverages on all schools and university campuses, including in private restaurants and bars that operated on university premises. In defense of this policy, Erdoğan said, "Should a student come to the university to get alcohol and get drunk, or receive education and find himself? How can we permit alcohol to be served on a university campus?"10

Another example is the government's vilification of mixed-gender housing (in dorms as well as private accommodations). Erdoğan said that the AKP

\footnotetext{
${ }^{8}$ On the "honor of the state," see, Parla 2001.

9 "Dindar Bir Gençlik Yetiștirmek Istiyoruz [We Want to Raise a Pious Youth.]" Hürriyet. 1 February 2012. http://www.hurriyet.com.tr/gundem/19819295.asp. Retrieved 13 May 2017.

10 "Üniversitede Alkol Yasağı." [Alcohol Ban in Universities]. Hürriyet. 8 September 2012. http://www. hurriyet.com.tr/universitede-alkol-yasagi-21411434. Retrieved 13 May 2017.
} 
government would not be allowing girls and boys to stay in the same dormitories run by the state, because, he noted, "as a conservative democrat party, everyone's children are our responsibility." 11 "It is unknown what is going on there. All kinds of messy things are happening. Parents are crying out, "Where is the state?' We have to show where the state is."12 Soon after these declarations, dorms that were co-ed started to place female students in separate buildings, and many landlords who had rented apartments to mixed-gender roommates started to terminate their contracts. On numerous other occasions, he said it is the duty of the state to protect the honor of the nation ${ }^{13}$ or to protect the youth from alcohol, gambling, and narcotics. ${ }^{14}$

The framing of citizens as unruly, immature teenagers who would fall victims to immorality and corruption, in the absence of a state, point to paternalistic type of patriarchal governance that allows the state to assume the role of the caring father who claims to know the best interests of his children. This is a form of the emasculation of the citizen achieved through their infantilization, which allows the state to take on the role of the benevolent father who is well justified in his protective, regulatory interventions to "correct" the lives of citizens.

Taking a similar paternalistic/authoritarian stance toward women and motherhood, Erdoğan frequently announced that each woman should have at least three children, the use of contraceptives is no different from treason, and abortion is no different from murder. $^{15}$

While the above examples demonstrate a paternalistic kind of protectionism, Erdoğan resorted, perhaps more frequently, to fraternal/egalitarian rhetoric, which interpellated citizens as wives or sisters. This form of address is vividly illustrated in a speech Erdoğan gave in 2013, where he used the famous, originally Persian, love story of Farhad and Shirin (Ferhat and Şirin in Turkish) as an analogy for the relationship between the state and the nation. This story, widely known in Turkey as an Anatolian version of the Romeo and Juliet story, tells of Ferhat's love that is so selfless and powerful that he dug through an impassible mountain to prove his love for and reach Şirin. In a public speech he gave during the opening of a new hospital, Erdoğan said,

\footnotetext{
11 "Evlerde Kızlı Erkekli Kalmaya Izin Yok." [Girls and Boys not Permitted to Live Together] Milliyet Haber, 5 November 2013. http://www.milliyet.com.tr/erdogan-dan-tartisilan-aciklamaya/siyaset/detay/1787437 /default.htm. Retrieved 13 May 2017.

${ }^{12}$ Cengiz, Orhan Kemal. "Erdogan's 'Morality Police' Assume Duty." Al Monitor. 6 November 2013. http://www.al-monitor.com/pulse/originals/2013/11/turkey-morality-police-erdogan.html\#. Retrieved 13 May 2017.

13 “T.C. Cumhurbașkanlığı: Devlet Övünç Madalyası Tevcih Töreni’nde Yaptıkları Konușma.” Official Site of the Presidency of the Republic of Turkey, 16 March 2015. http://www.tccb.gov.tr/konusmalar/353/29802 /devlet-ovunc-madalyasi-tevcih-toreninde-yaptiklari-konusma.html. Retrieved 13 May 2017.

14 "Mahalle Baskisı Yapmak Lazım." [Social pressure is needed] NTV, 5 March 2015. http://www.ntv.com. tr/turkiye/cumhurbaskani-erdogan-mahalle-baskisi-yapmak-lazim,fNzX10wBcEOny1vy2kjP6w. Retrieved 13 May 2017.

15 “Erdoğan: Kürtaj Bir Cinayettir.” [Erdoğan: Abortion is Murder] Milliye Habert, 26 May 2012. http://www. milliyet.com.tr/erdogan-kurtaj-bir-cinayettir/siyaset/siyasetdetay/26.05.2012/1545254/default.htm. Retrieved 13 May 2017.
} 
We are like Ferhat and Şirin. We are Ferhat and you are Şirin. Ferhat dug through mountains. They told us that you cannot dig through mountains, but we did. We are digging through mountains with tunnels. We are overcoming obstacles that everyone said were impassable. Why do we want to reach Şirin? We brought together our nation with the state. But those before us could not do this, they turned the nation and the state into enemies. ${ }^{16}$

With this telling analogy, Erdoğan not only establishes the Turkish state as the selfless loving male subject and the nation as the female object of desire, but also vests the state with masculine power that can overcome even the toughest of obstacles to come together with its nation. The marking of the feminized citizen as the beloved frames the state's services as being done in the name of love, which serves to negate even the possibility that the state might be acting in the interests of any other group, class, or ideology, and establishes that the policies of the government are being done with the best interests of citizens at heart. This rhetorical strategy disempowers the citizen by making it very difficult, if not impossible, to demand anything other than what the state offers. The citizen is emasculated into having to accept passively whatever the state deems they deserve, and since no one would want to be in a position to break a lover's heart, they are burdened with guilt should the thought of criticizing or rejecting the offer cross their mind. Furthermore, Erdoğan also establishes former governments (referring to all the pre-AKP regimes, which ruled under Turkey's official secular founding ideology, Kemalism) as being an enemy of the Turkish nation, therefore projecting the AKP as saving the nation from Kemalism, framed here as an implied abusive and oppressive former "husband" (government) to the Turkish nation. ${ }^{17}$

Indicating that Erdoğan's alignment with the fraternal type of patriarchy is a conscious choice, he has intentionally resisted being called a father, and on many occasions asked crowds chanting "Tayyip Baba" not to refer to him in this way. He said, "Don't call me father. We did not come here to be your superior, or a patriarch, we came here to serve you. That is our uniqueness."18 Here, Erdoğan is using the term patriarchy in the first meaning of the term to refer to a kind of paternalistic, oppressive power that is common to authoritarian governments, which, he implies, was an attribute of previous governments in Turkey. He projects himself and the AKP as being unique in treating citizens not as subordinates as former [Kemalist] regimes have done, but as equals.

At Gezi, the escalation of violence that started after the police came down upon the protestors with excessive force, resulting in serious injuries and deaths, was blamed on the protestors. The AKP government justified these repressive measures by the projection of impending anarchy and violence targeting the lives of citizens. Erdoğan came down hard on the protestors, accusing them of acts of vandalism and aggression against

\footnotetext{
${ }^{16}$ R.T. Erdoğan, "Biz Ferhat'1z siz Șirinsiniz" [We are Ferhat, You are Șirin] Akasyam Haber, 30 September 2013, http://www.akasyam.com/biz-ferhatiz-siz-sirinsiniz-9810/. Retrieved 01 Aug 2016.

${ }^{17}$ Kemalism, named after Mustafa Kemal Atatürk, upholds secularism, modernization, and Westernization, and has been the basis of all three constitutions of the Turkish Republic.

18 “Erdoğan: Ne olur bana bunu demeyin.” [Erdoğan: Please don’t call me that]. Yeni Şafak. 12 March 2014. http://www.yenisafak.com/video-galeri/politika/erdogan-ne-olur-bana-bunu-demeyin-14403. Retrieved 13 May 2017.
} 
"his" pious citizens. ${ }^{19}$ In his addresses, he often limited the citizenry that he claims to protect, to conservative and pious people who have voted for the AKP. On numerous occasions, he referred to "his citizens" as the $50 \%$ of the voters who had voted for the AKP in 2011. During the Gezi Park demonstrations, Erdoğan said

as a prime minister, a citizen, and an Istanbulite, I am telling you that if we put aside innocent, unknowing participants who got involved in the demonstrations due to the sentimental messages they received via the social media, the events were organized by radical groups. These don't really care about Gezi Park.... Right now, we are showing every effort to hold back at least 50 percent of the country so that they stay at home and do not take it to the streets. We are telling them to be patient and not be tricked into these games. ${ }^{20}$

This statement not only emasculates the protestors as innocent, unknowing, gullible participants, but also frames them as borderline citizens who risk losing their citizenship status should they continue with the protests, where the state can no longer provide them protection from threats, including the anger of the AKP's supporters, who are marked as more loyal, worthy citizens.

Midway through the protests, the government started to blame "foreign powers" for instigating the protests, which further served to emasculate the protestors by denying them the agency and will to undertake such action on their own. Erdoğan maintained that the "interest lobby" and the enemies of Turkey were behind the protests and manipulated the protestors to serve their malicious aims. He said to the protestors: "you were all used as voluntary militants in a game that you could not understand; you have been deceived and made victims of such a plot." ${ }^{21} \mathrm{He}$ invariably addressed the protestors as "young children" and spoke to them in the tone of a protective father, warning them not to "fall prey to the games of illegal organizations." 22 In these statements, instead of addressing the protestors directly, he often addressed their parents asking them to remove their children from the streets.

These statements illustrate rhetorical strategies with which citizens are emasculated into infantile, gullible, ignorant little children who are incapable of making the right choices and therefore continually need to be monitored and shepherded. Also, by pointing at an outside force that threatens Turkey's security by creating disorder, Erdoğan establishes the state as the necessary and only viable protector who is looking

\footnotetext{
${ }^{19}$ See, for example, "Bașbakan: Bu Tayyip Erdoğan değișmez [Erdoğan: This Tayyip Erdoğan Will not Change].” Hürriyet. 12 June 2013. http://www.hurriyet.com.tr/gundem/23479966.asp. Retrieved 13 May 2017.

20 “Erdoğan: 'Türkiye'nin yüzde 50'sini zor tutuyoruz' [We can hardly hold back $50 \%$ of Turkey]" Milliyet Haber. 3 June 2013. http://www.milliyet.com.tr/basbakan-4-gun-yok/siyaset/detay/1717873/default.htm. Retrieved 15 May 2017.

21 "Interest lobby" is a term used by the AKP circles to refer to the international banking and financial sector, which operates based on the anti-Islamic principle of financial interest. Erdoğan frequently uses the term to refer to an alleged conspiracy of foreign and domestic economic actors who want to destabilize Turkey for economic gains. "Erdoğan: Gezi gençleri faiz lobisinin neferi oldu [The Gezi Youth have become soldiers for the Interest Lobby.]" NTV. 22 June 2013. http://www.ntv.com.tr/turkiye/erdogan-faiz-lobisinin-neferioldular,hRBnD9YIYkehfPQCWqTF4g. Retrieved 15 May 2017.

22 “'Başbakan Erdoğan: 'Avrupa Parlamentosu'nun Kararını Tanımıyorum.' [Prime Minister Erdoğan: I do not Recognize the Decision of the European Parliament.]" Bianet. 13 June 2013. http://www.bianet. org/bianet/siyaset/147529-avrupa-parlamentosu-nun-kararini-tanimiyorum. Retrieved 15 May 2017.
} 
out for the interests of his citizens and providing for their safety against anarchy, chaos, and violence.

\section{The possibility of a post-patriarchal state}

The main premise of this study is that the core objective of Gezi protests was to object to the logic of representation of interest that the state defines as a need for protection, which it uses to justify its overbearing regulatory and remedial interventions in its attempts to establish itself as the ultimate source of power and authority. I have argued that this logic of patriarchal protection is an inherent feature of the social contract, which lays the conceptual foundations of the modern state. The primary target of the Gezi protests was this patriarchal, protectionist rhetoric that the state used to interpellate the citizen as an emasculated subject.

Gezi protestors not only targeted, but also subversively used the rhetorical devices and metaphors used against them by the state to position themselves against the state's patronizing, disabling, and disempowering interventions. The main goal of the protests was to reject the model citizen role tailored for them by the state, which emasculated them by reducing them to the status of children, or by feminizing them as mothers, daughters, or sisters, who are not capable of making decisions for themselves and are in constant need for a father or a brother who looks out for and protects their interests. The protesters sought to unsettle the patriarchal premises of authority by severing the paternal or fraternal ties that bound them to the state. They creatively used humor to subvert the state's attempts to emasculate them, shed this tailored citizenship suit that had become too tight (see Image 9 later in this article), and instead celebrated the preservation of individual autonomy. I interpret this celebration as a call for the end of not only the paternalistic type of patriarchy that fuels authoritarian governmental forms and interventions, but also fraternal/egalitarian patriarchy that fuels regulatory and remedial interventions common in democratic forms of governance, both of which are justified through the state's claim that it is acting in the best interests of the people that are defined as needing protection. This article argues that the objection to the logic of representation of interest and the protest of ensuing protective and regulatory interventions of the state signify a call for a post-patriarchal state where the relationship between the state and the citizens is no longer established on the projection of threat or a promise of protection.

During the protests, humor and irony were used effectively as subversive techniques to overturn the rhetorical devices and metaphors employed by the government in building and justifying its authority. Through what Butler refers to as "the parodic replication and resignification" (1996, p. 380), these devices and metaphors were imitated and reversed in ways that not only exposed the oppressiveness of the intervention, but also subverted their authority by overturning the metaphor into its opposite meaning, or by performing the role in ways that countermands the intended effect. Many of the slogans and statements made by the protestors utilized this method of subversion through reversal of the metaphor. As illustrated here, by situating citizens into the position of helpless, emasculated subjects in need of protection (as children, wives, or sisters), Erdoğan inadvertently created the space for a language of protest that replaces the child metaphor with the trope of a rebellious teenager protesting his/her domineering parents, or the helpless wife metaphor with a disgruntled woman who 
wants to be free of her abusive husband. This form of subversion through reversal of the same metaphor is evident, for example, in the voice of the unhappy wife that the Gezi protestors adopt when they attempt to "divorce" Erdoğan through the method of talaq, as expressed in the graffiti "Talaq Tayyip, talaq!” (Korkman and Açıssöz 2013) "Talaq" refers to the way divorce took place for Muslims under Sharia law in the Ottoman Empire, which was done by uttering the phrase "Boş ol" ("I divorce you”). By using this obsolete word, the protestors not only frame Erdoğan as an old-fashioned fundamentalist, but also regain the agency he denies them by choosing to "divorce" him and overturning the submissive role that is assigned to them.

One such example of the use of irony are the mock-AKP campaign posters (see Image 2) that circulated in the social media during Gezi protests, which illustrate the objection to the kind of regulatory interventionism of the fraternal/patriarchal state through a display of the absurdity of the remedial undertakings of the AKP when they are carried out in a different context. These posters mock the way the AKP is trying to "improve" lives by "fixing" things like the Coliseum or by building a shopping mall in Hyde Park.

A popular example of the subversive use of irony through the reversal of the metaphor is the adoption of the word "Çapulcu" and its anglicized version "Çapuling" as well as the word "Çapulistan" (referring to the makeshift camp set up at the Park) by the protestors (see Image 3). Originally meaning marauder, the word Çapulcu was first used by Erdoğan to frame the demonstrators as mere vandals, who deserve harsh repressive measures. The protestors quickly appropriated the term by reversing it to mean 'those who disrupt order through their humor,' which then spread through the social media to become a globally recognized popular word that describes the protestors.

Another example of subversion through reversal of the metaphor is the adoption of the role of the gullible, infantile youth that needs to be shepherded and guided by the state but performing it in ways that turns the intention of the state against it. To Erdoğan, who repeatedly stated that women need to give birth to at least three children, the protestors ask: "Are you sure you want three children like us?" (see Image 4), thereby turning his belittlement and criminalization of the protestors against him and exposing the kind of constricted citizenship model that is being imposed on them.

Another similar example of reversal of the metaphor is one of the popular slogans that states: "Don't worry mom, we are at the back rows," (see Image 5) making a reference to those who were injured by police brutality often hitting those at the front rows. This statement has multiple functions. First, it gives the message that the participant is not endangering themselves by being at the frontlines, thereby assuming the voice of a child but only to subvert it by demonstrating that they are capable of rational decision-making and looking after themselves. What is even more interesting here is that it exposes the irony of the state's claim that it is protecting its citizens, when in fact it is the source of threat itself.

When the government wanted to convey messages to the protestors during the protests, it often did so not by addressing them directly but talking to their parents instead. Erdoğan and other officials frequently assigned mothers the duty of ensuring that their children are obedient and dutiful citizens, and asked them to keep their children away from the streets. $^{23}$ These calls not only diminished the importance of the demands of the protesters

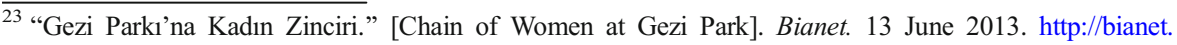
org/bianet/toplum/147555-gezi-parki-na-kadin-zinciri, Retrieved 15 May 2017.
} 


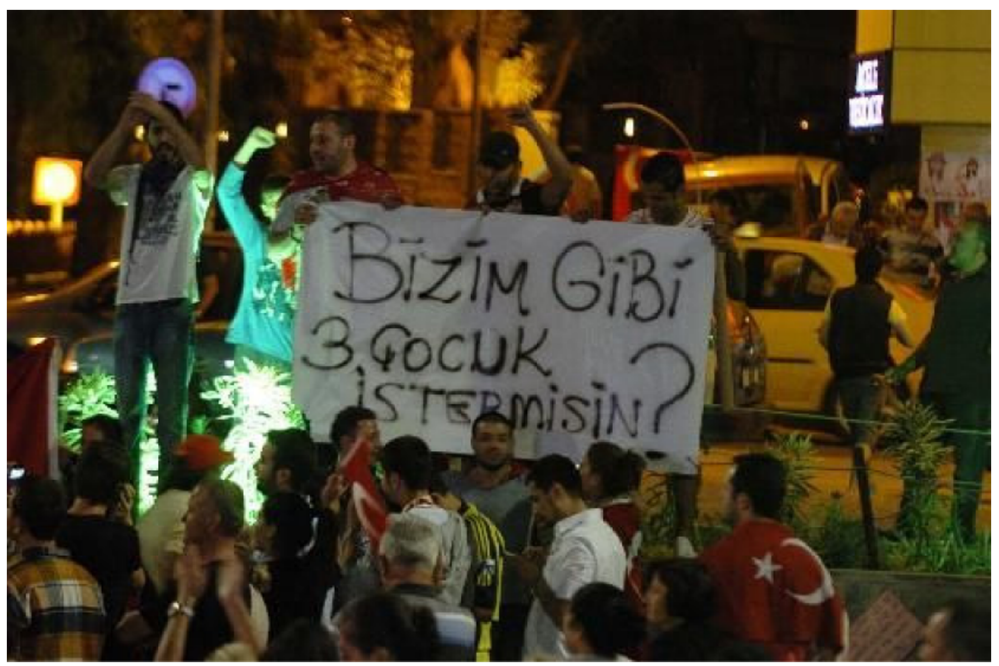

Image 4 "Would you like 3 children like us?" (http://duvardageziparki.tumblr.com/page/15)

by framing them as children and denied them agency, but also reaffirmed the state's claim to the representation of interest by placing it in the position of a husband who delegates his wife to parent their children. In response to this paternalist emasculation, this time mothers themselves took to the streets and gathered at Gezi Park to create a circle around their children to protect them from the police. These women, who chose to participate in the protests by dancing, banging on pots and pans, singing, and even cooking to support their children (see Image 6), resorted to the reversal-of-the-metaphor technique to subvert the role of motherhood imposed on them by the state by accepting the role but using this authorization for its opposite purpose by becoming protestors themselves. They also subversively imitated the voice of the state to address the mothers, not of the protestors, but of the police officers attacking the demonstrators: "Dear mothers of the police," they

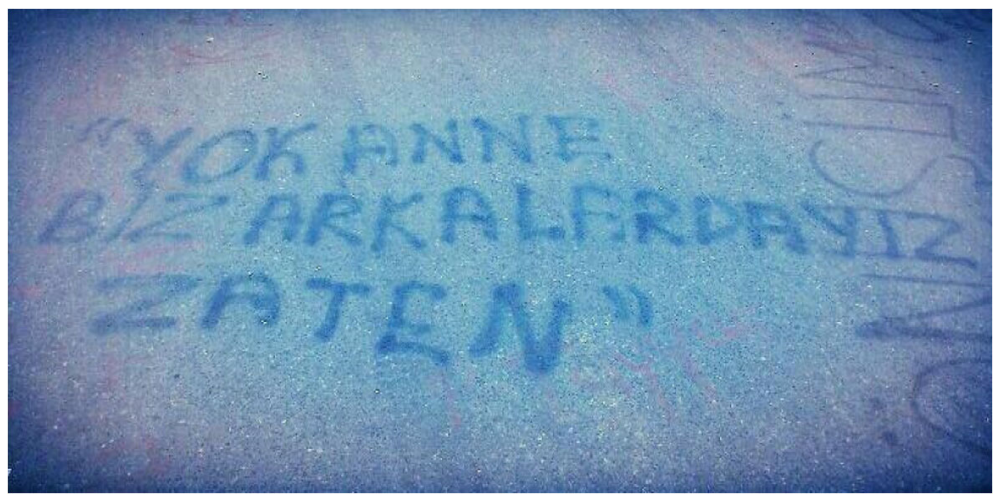

Image 5 "Don't worry Mom, we are at the back rows." (http://www.ohadiyorumm.com/tag/geziparki-duvar-yazilari/) 


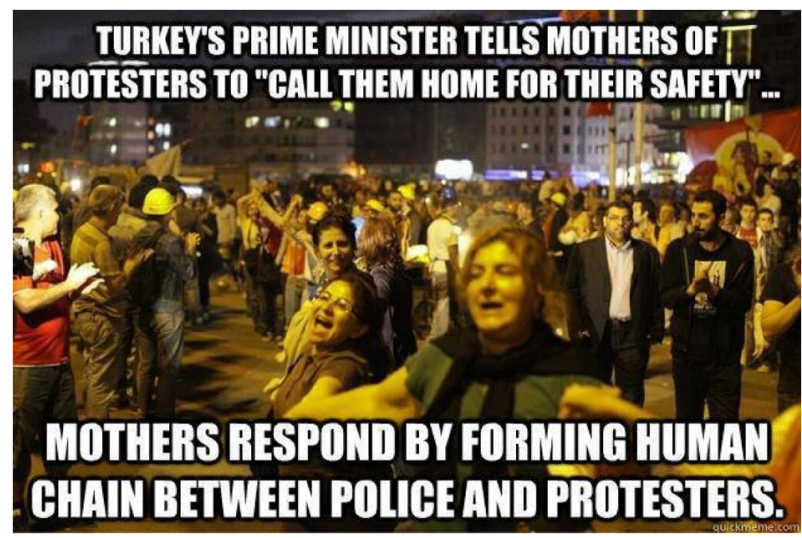

Image 6 Mothers at Gezi subversively responding to the call of the authorities to remove their children from the protests by joining their children in support of the protests. https:/elfkat.wordpress.com/tag/turkey/

hailed, "please remove your children from the park." ${ }^{24}$ This parodic replication of the official rhetoric not only allowed the mothers to re-empower the protestors by using their parental authority to sanction and legitimize their cause, but also to use the same technique of emasculation on the police - the epitome of masculine power-themselves, thereby exposing the fictitiousness and absurdity of the infantilization of the protestors.

This move by the mothers, in turn, fueled the use of the motherhood trope in further creative and subversive ways (see Images 7 and 8). As knitting laces is a popular image in Turkey associated with the housewife trope, laced images became symbols of mothers' involvement in the movement that subverted the "protective paternalism" function ascribed to the family by the state.

Perhaps the most important aspect of the protests was the objection to the citizenship model that was imposed onto citizens, which not only emasculated them but also aggregated them into a homogenous community as generic subjects in ways that dismiss individuality and individual autonomy. To contest such totalizing interventions, protestors creatively resorted to a particular school of Turkish poetry, the "Ikinci Yeni [Second New]" movement of the 1950s, which is one of the milestones in Turkish literature known for its abstract, esoteric, multilayered imaginary, an existential exploration of the self, and the empowerment of the voice of the individual (Günay-Erkol 2013, p. 116; Halman 2013, p. 82). These poets shied away from the certainties and totalizing statements of their modernist, Marxist, or Kemalist counterparts and celebrated the uniqueness of the individual, as opposed to the trivialization of the individual to the benefit of the community. The widespread use of these poems during the Gezi demonstrations ${ }^{25}$ carries the celebration of the autonomy of the individual to the streets half-a century later, and it makes a statement against

\footnotetext{
${ }^{24}$ Ibid.

${ }^{25}$ Erdem Çolak draws attention to the widespread use of Second New verses by the Gezi protestors and points out that this movement later organized under names such as the "Second New" or \#siirsokakta (poems in street) in the social media (2014, p. 472).
} 


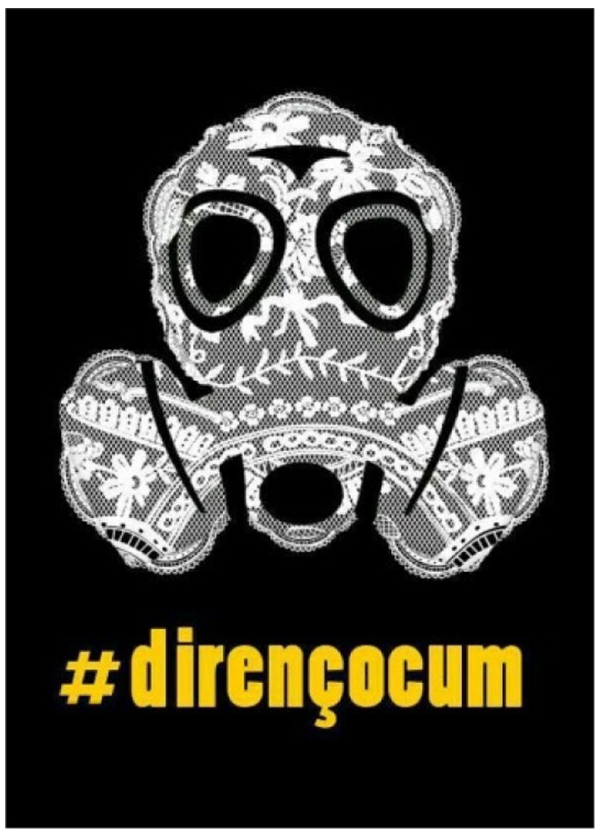

Image 7 “\#Resist my child": A Twitter hashtag using a 'laced' gas mask icon which became one of the symbols of the resistance against police brutality during the protests. http://everywheretaksim. net/tr/posterler/?nggpage $=4$

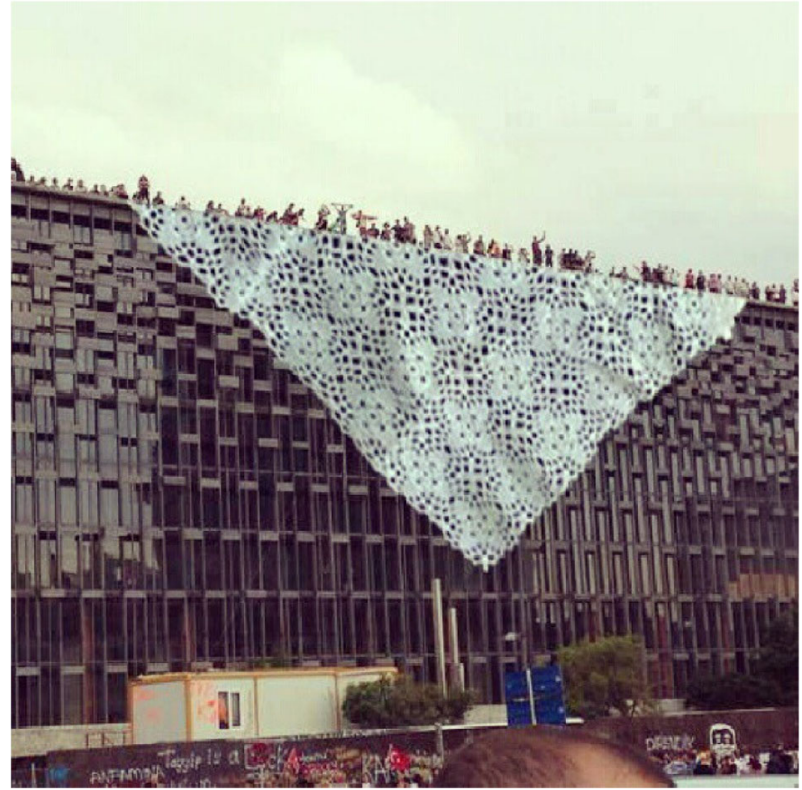

Image 8 The building with a giant lace on it is the Atatürk Cultural Center, a key landmark on Taksim Square where the Gezi protests took place. The lace is reminiscent of traditional households where laces are placed in a similar way on television sets and other furniture, making a reference to the traditional housewife image, who now has a subversive presence among the protestors. This building was later demolished by the AKP government in 2018. https://www.mothervoices.org/column/2016/3/2/february-2016-oda-projesi-tr 
such totalizing interventions to call for the recognition and expansion of the freedom of the individual. As Images 9 and 10 illustrate, the poems of one of the popular Second New poets Turgut Uyar was widely used by the protestors. Image 9 depicts a famous line by Uyar that reads: "Whoever has been tailoring the dress for years has been doing it wrongly/ It is a dress way too tight." The use of this quote in the context of Gezi makes a reference to the model citizen role that the state tailors, but one that protestors find "too tight" and constraining.

Image 10 is perhaps the ultimate example of a post-patriarchal understanding of citizenship that is invoked against the state's attempt to discipline citizens into a tightly defined role as obedient, hard-working, model citizens who dutifully serve their country in ways that the state expects of them. Uyar's famous poem, Göge Bakma Durağl (The Bus Stop to Look at the Sky) is a deliberately vague juxtaposition of a functional location (bus stop) with a completely arbitrary, apolitical, and individual practice (looking at the sky). It does not carry an openly political message, but as implied in the performative display of the demonstrators posing under the banner that recites the poem, it unites people around a joyful and optimistic attitude and a very individualistic act, as if to say, "I am an autonomous individual who will do as I please, even if it is such a trivial act of looking at the sky" (see Image 10). What makes this statement political in the context of Gezi is that it implies dissent against the state that has been constantly telling its 'infantilized' citizens how to behave and what to do, and that this arbitrary, individual act is done collectively as if it is the collective choice of citizens to be independent, free individuals. This telling statement also indirectly subverts the state's attempts to establish norms of citizenship along the lines of serving one's country or doing meaningful deeds for the benefit of the national community, by offering an alternative (post-patriarchal) notion of citizenship as defined by individual autonomy. In the scene, the presence of women and men with different lifestyles, fashion senses, and beliefs is also a response to the governing mentality that tries to utilize old cleavages based on the Islam-secular dichotomy and tries to categorize citizens accordingly. This odd gathering can be read as the articulation of the desire to be recognized as autonomous individuals with different, non-totalizable, unique interests, desires, values, and opinions.

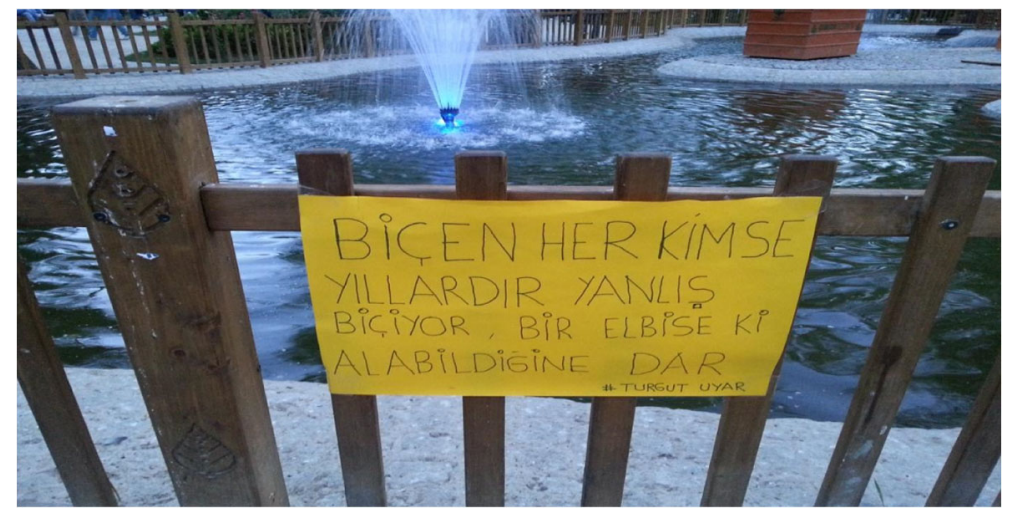

Image 9 "Whoever has been tailoring the dress for years has been doing it wrongly/ It is a dress way too tight." Turgut Uyar http://erkansaka.net/senay-cinar-hepimiz-turgut-uyarin-dizeleriyiz/ 


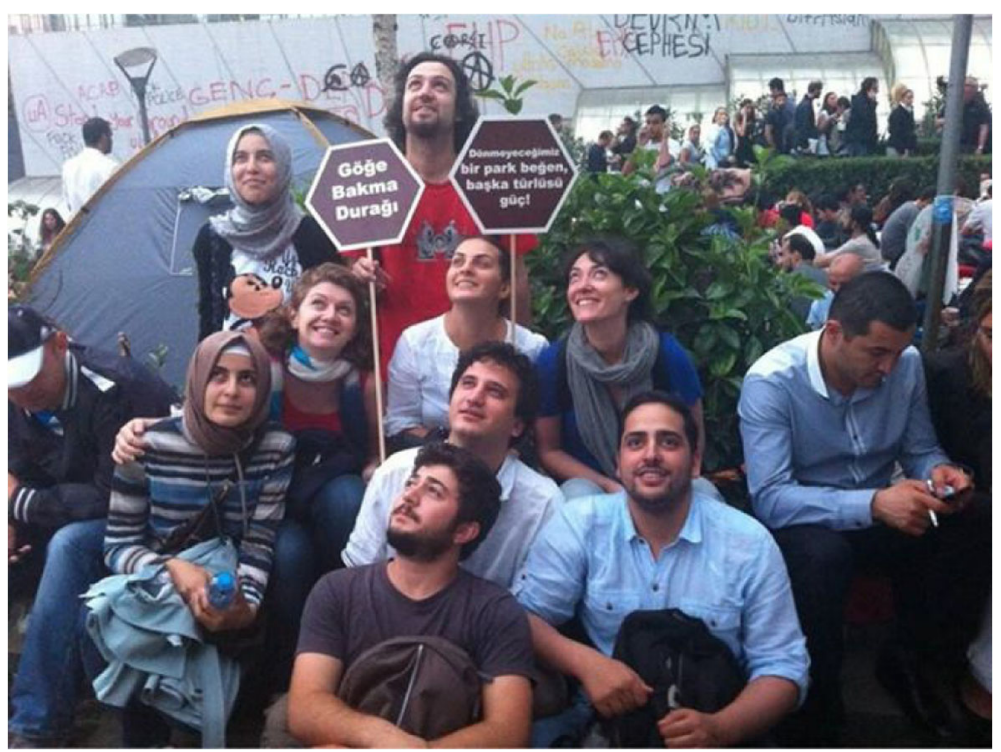

Image 10 "The Bus Stop to Look at the Sky" [reference to Uyar's famous poem]. (http://erkansaka.net/senaycinar-hepimiz-turgut-uyarin-dizeleriyiz/)

The protests at Gezi Park ended with a dramatic but highly significant incident that became a globally recognized signature form of protest referred to as the "Standing Man" event. On June 15 Erdoğan asked the protestors to terminate the demonstrations and vacate Taksim Square, the area adjacent to Gezi Park. When the protestors refused, the government came down hard, resulting in night-long violent clashes between the protestors and the police, and by next morning the police had taken control of Taksim, arrested hundreds of protestors, and left behind many injured, including 14-year-old Berkin Elvan, who was hit in the head by a pepper gas canister and later died after

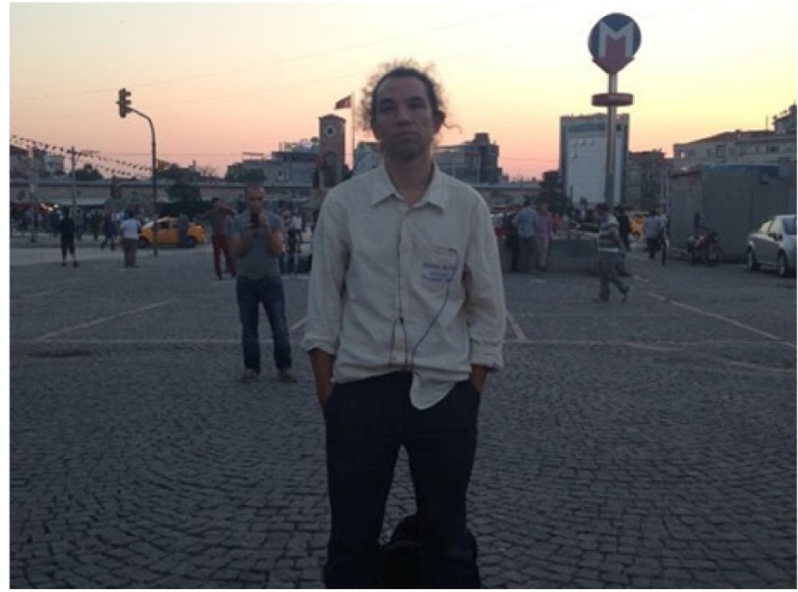

Image 11 The Standing Man: a new form of non-violent protest. http://www.baskahaber.org/2013/06/duranadam-erdem-gunduz-konustu-bir-sey.html 


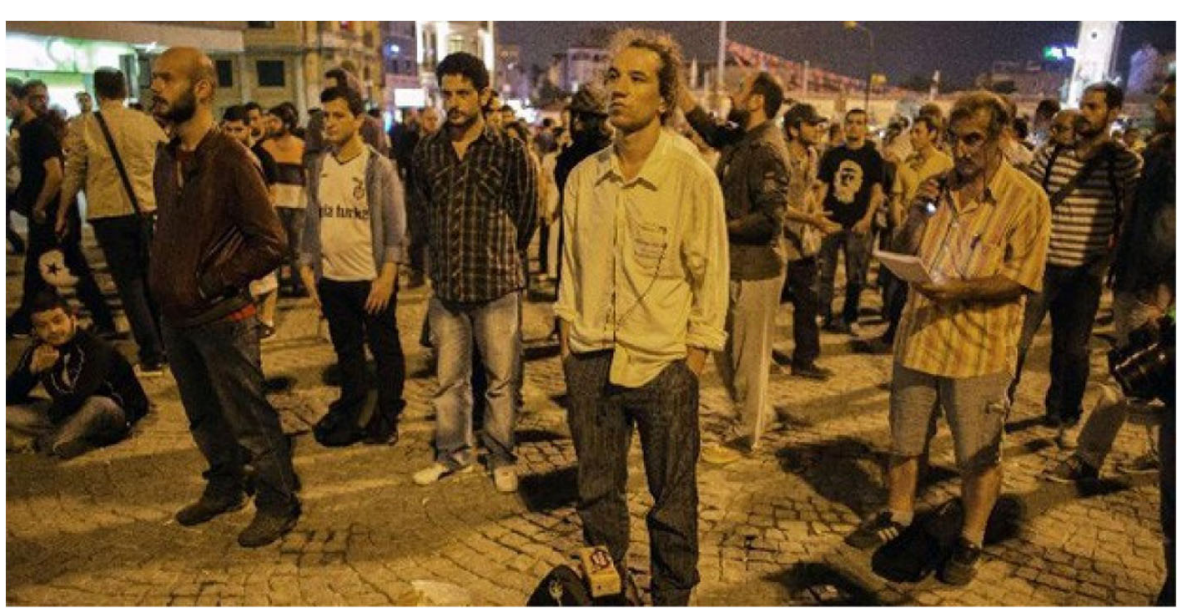

Image 12 The Standing Man is joined by a growing number of protestors who stood as independent individuals but protesting collectively. https://t24.com.tr/haber/13-kose-yazarindan-duran-adamyorumlari, 232308

being in intensive care for nine months. After this date, all gatherings at Taksim were disallowed, but this violent crackdown sparked further protests all over the country, which continued for 9-10 more weeks in the form of violent clashes that resulted in thousands of arrests, hundreds injured, and more than a dozen deaths. Two days after the ban at Taksim, however, a protestor, Erdem Gündüz, appeared on the Square, alone, and started standing with his gaze fixed on the Atatürk Cultural Center, which had been occupied by the protestors just a few days earlier, now covered with a giant Turkish flag. He stood for eight hours straight without moving or making a sound. Emphasizing the significance of a single individual in facing the state, now embodied by the giant flag that covered the site of the protests, this performance made a silent but powerful statement against the state that had ordered its citizens to end the protests and vacate the grounds. The presence of the Standing Man at the Square not only reclaimed the power of the emasculated citizen back by defying the state's orders, but also underlined the main demand of the protests: the recognition of the individual authonomy of the citizen. The silence and the inaction also subverted the state's claim that the protesters had become violent and disruptive. After the news spread through the social media, several others started to join (see Images 11 and 12). In a matter of hours, Taksim Square was again full of several protestors who were just standing there, independent as single individuals, but also collectively doing the same thing by doing nothing. The Standing Man fast became a globally recognized phenomenon, celebrated in different countries in support of Gezi, and later won the M100 Sanssouci Colloquium Media award in Germany for displaying a form of nonviolent protest in defense of freedom of expression. In a later interview, Gündüz said that he was not protesting the government, he was protesting the whole system, because even if it was replaced by another government, the way governments treat citizens would not change and they would continue to do things claiming that these are in the public interest, but that only end up trampling freedoms (İzci 2013). But then he emphasized that what he thought did not matter, because he was just one among many. "What really matters is the protestors themselves," he said, and added: "they resisted for 19-20 days straight. ... They are the ones who made a difference." 


\section{Conclusion}

There is no doubt that Gezi Park protests have become one of the most important historical milestones in Turkey, and possibly in the world as part of other similar protests from the Occupy, or the Arab uprisings, to Spain's 15 M movement that have been erupting since 2011. Even though Gezi protests ended in August 2013 after they were violently suppressed by the police, it became clear soon after that it was not an end but a new beginning. Since then, Gezi has become one of the key markers of a new type of politics in Turkey. Some have drawn attention to "a new urban awareness" or "new forms of citizenship" (Göle 2013, pp. 9, 14) that it created; others focused on the invention of new spaces of activism which were "imagined outside the conventional frameworks of political participation or contestation" (Ay and Miraftab 2016, p. 571). But perhaps it is Erdoğan's consistent referral to Gezi to this day, when he keeps blaming any opposition or criticism directed at him or the AKP for being irresponsible, immoral, and wreckful like Gezi protestors, that is the best indicator of the significance and extent to which Gezi has impacted politics in Turkey. ${ }^{26}$ Apart from becoming the symbol of resistance, and the possibility of a new type of nonpartisan, non-totalizing, post-patriarchal politics, the "Gezi spirit," as one author calls it, (Bakıner 2014:65) lives on in several forums, grassroots organizations, and platforms that were formed during Gezi and continue to be actively involved in various protest and resistance movements, such as the Cerattepe and Yeşilyol environmentalist mobilizations since then.

This study takes the Gezi protests as the Turkish version of a global surge of protest movements starting in 2011 that contest the logic of representation of interest, which, I argue, is used by the modern state as justification to establish its authority and in its attempts to regulate the lives of citizens. I have discussed that such forms of governance are not specific to a particular government, or part of a certain political regime, but rather are extensions of the foundational rationality of the modern state, which is inherently patriarchal, in both its authoritarian and democratic forms, defined as the employment of a logic of protection and the use of masculinity and femininity as metaphors to establish and legitimize its authority, and to construct, enforce, and monitor a regime of citizenship where citizens can only function as emasculated subjects dependent on the protection of the state. Based on an analysis of the addresses of Erdoğan, and the subversive use of humor and irony by the protestors, this article demonstrates that the protests target the state's disciplinary, regulatory, and remedial interventions that impose a restrictive model of citizenship which reduces citizens into generic subjects who can only speak with the voice of the nation and are denied an autonomous voice. I conclude that objecting to these modern forms of subjugation, the Gezi Park protests call for a post-patriarchal state where it no longer resorts to a patriarchal protectionist logic which is justified through the claim that it represents the interests of its citizens. By envisioning such a post-patriarchal state, I interpret the

\footnotetext{
${ }^{26}$ See, for example, "Erdoğan: Herkes uzaya gitmekle meşgulken Gezi Parkı'nda oynadılar [They have played at the Gezi Park while everyone was busy doing space travel].” BirGün. 24 March 2017. http://www. birgun.net/haber-detay/erdogan-herkes-uzaya-gitmekle-mesgulken-gezi-parki-nda-oynadilar-152460.html. Retrieved 15 May 2017; "Erdoğan: Gezi olaylarındaki gibi, gençlerimize bedava alkol dağıtmaktan geri durmuyorlar! [Just like in the case of Gezi events, they are giving away free alcohol to our youth!]" T24. 3 March 2017. http://t24.com.tr/haber/erdogan-gezi-olaylarindaki-gibi-genclerimize-bedava-alkol-dagitmaktangeri-durmuyorlar,391914. Retrieved 15 May 2017.
} 
protests as a call for the renegotiation of the social contract such that the statecitizenship relationship is radically reformulated to enable a more empowered and autonomous citizen.

Since the protests, and especially after the failed coup attempt of July 2016, the AKP government has made it increasingly costlier for protesters to take to the streets by using excessive force, incarcerating people in the tens of thousands, and passing legislation that is increasingly coercive. ${ }^{27}$ In 2019 , the government took the crackdown on the protestors to a new level when a bill of indictment was issued against sixteen civil-rights activists for their involvement in the organization of the Gezi protests charging them with "attempting to overthrow the government." 28 Yet, the invitation to a post-patriarchal state lives on venues such as social media, various grassroots networks across the country, as well public forums that are still being held regularly in different parts of Turkey.

Acknowledgements I am indebted to my dear friend and colleague Meral Uğur Çınar who has been part of this study since its conception. This article would not have been possible without her insightful observations, creative input, and invaluable contributions made at every step of the research and preparation of the manuscript. Translations of the source titles are by Meral Uğur Çınar; all other translations are by the author.

\section{References}

Acemoğlu, D. (2013). Development won't ensure democracy in Turkey. The New York Times June 5.

Akyüz, S. (2012). Political manhood in 2000's Turkey : Representations of different masculinities in politics. Thesis: Bilkent University, Ankara.

Althusser, L. (2014). On the reproduction of capitalism: Ideology and ideological state apparatuses. New York: Verso.

Altınay, A. G. (2004). The myth of the military-nation: Militarism, gender, and education in Turkey. Dordrecht: Springer.

Arat, Y. (1997). The project of modernity and women in Turkey. In S. Bozdoğan \& R. Kasaba (Eds.), Rethinking modernity and national identity in turkey (pp. 95-112). Seattle: University of Washington Press.

Arat, Y. (2000). Gender and citizenship in Turkey. In S. Joseph (Ed.), Gender and citizenship in the Middle East (pp. 275-287). Syracuse: Syracuse University Press.

Ataman, H. (2011). Less than citizens: The lesbian, gay, bisexual, and transgender question in Turkey. In R. Ö. Dönmez \& P. Enneli (Eds.), Societal peace and ideal citizenship for Turkey (pp. 125-159). Plymouth: Lexington Books.

Ay, D., \& Miraftab, F. (2016). Invented spaces of activism: Gezi Park and performative practices of citizenship. In J. Grugel \& D. Hammett (Eds.), The palgrave handbook of international development (pp. 555-574). UK: Palgrave Macmillan.

Aytaç, S. E., Schiumerini, L., \& Stokes, S. (2017). Protests and repression in new democracies. Perspectives on Politics, 15(1), 62-82.

Azzellini, D., \& Sitrin, M. (2014). They can't represent us! Reinventing democracy from Greece to occupy. In London. New York: Verso.

\footnotetext{
${ }^{27}$ On the details of the Internal Security Package, see Kadri Gürsel, "Turkey's perilous security package." $\mathrm{Al}$ Monitor. 20 February 2015. http://www.al-monitor.com/pulse/originals/2015/02/turkey-securitypackage-threatens-security.html, Retrieved 15 May 2017. After the declaration of State of Emergency following the 2016 July coup attempt, measures against all forms of protest have been suppressed by increasingly aggressive means.

28 İstanbul BIA News Desk. 20 February 2019. "Osman Kavala, 15 Rights Defenders Facing Life Sentence Over Gezi Park Protests.” Bianet - English. https://www.bianet.org/english/law/205683-osman-kavala-15rights-defenders-facing-life-sentence-over-gezi-park-protests. Retrieved March 23, 2019.
} 
Bakıner, O. (2014). Can the 'spirit of Gezi' transform progressive politics in Turkey? in The Making of a Protest Movement in Turkey: \#occupygezi, edited by U. Özkırımlı. Springer.

Bassel, L. (2008). Citizenship as interpellation: Refugee women and the state. Government and Opposition, 43(2), 293-314.

Baydar, G. (2002). Tenuous boundaries: Women, domesticity and nationhood in 1930s Turkey. The Journal of Architecture, 7(3), 229-244.

Bozkır, G. (2010). İzmir Basınında Mustafa Kemal Atatürk’ün Kastamonu Gezisi. Çağdaş Türkiye Tarihi Araştırmaları Dergisi, 9(20), 109-126.

Brown, W. (1992). Finding the man in the state. Feminist Studies, 18(1), 7-34.

Butler, J. (1990). Performative acts and gender constitution: An essay in phenomenology and feminist theory. pp. 270-282 in Performing feminisms: Feminist critical theory and theatre, edited by S.-E. Case. JHU Press.

Butler, J. (1996). Imitation and gender insubordination. In A. Garry \& M. Pearsall (Eds.), Women, knowledge, and reality: Explorations in feminist philosophy (pp. 371-387). New York: Routledge.

Butler, J. (1997). The psychic life of power: Theories in subjection (1st ed.). Stanford: Stanford University Press.

Çiçekoğlu, F. (2019). The secular army or the new ottoman fantasy? Negotiating hegemonic masculinity in the image of İstanbul. In F. Çiçekoğlu \& Ö. Turan (Eds.), The dubious case of a failed coup: Militarism, masculinities, and 15 July in Turkey (pp. 91-121). Singapore: Springer Singapore.

Çınar, A. (2005). Modernity, islam, and secularism in Turkey: Bodies, places, and time. Minneapolis: University of Minnesota Press.

Çinar, A. (2008). Subversion and subjugation in the public sphere: Secularism and the Islamic headscarf. Signs, 33(4), 891-913.

Çınar, A. (2010). Globalism as the product of nationalism founding ideology and the erasure of the local in Turkey. Theory, Culture and Society, 27(4), 90-118.

Çinar, M. (2018). From moderation to de-moderation: Democratic backsliding of the AKP in Turkey. pp. (pp. 127-157 in The Politics of Islamism). Springer.

Çınar, Ö. H., \& Üsterci, C. (Eds.). (2009). Conscientious objection: Resisting militarized society. London: Zed Books Ltd..

CNN Türk. (2014). Erdoğan'dan Berkin Elvan Yorumu: 'Terör Örgütlerinin Mașasıydı. CNN Türk, October 21.

Çolak, E. (2014). Art in street: The significant role of using the art, literature and humor in the Gezi resistance. International Journal of Arts and Sciences, 7(4), 463-476.

Çolak, M. (2017). Bülent Ecevit: Karaoğlan. İletișim Yayınları.

Coole, D. (2003). Women, gender and contract: Feminist interpretations. pp. 193-211 in The social contract from hobbes to rawls, edited by D. Boucher and P. Kelly. Routledge.

Coșar, S., \& Yeğenoğlu, M. (2011). New grounds for patriarchy in Turkey? Gender policy in the age of AKP. South European Society and Politics, 16(4), 555-573.

Dağı, İ. D. (2008). Turkey's AKP in power. Journal of Democracy, 19(3), 25-30.

Damar, E. (2016). Radicalisation of politics and production of new alternatives: Rethinking the secular/ Islamic divide after the Gezi Park protests in Turkey. Journal of Contemporary European Studies, 24(2), 207-222.

Dean, M. (1992). Pateman's dilemma. Theory and Society, 21(1), 121-130.

Dönmez, R. Ö., \& Özmen, F. A. (2013). Gendered identities: Criticizing patriarchy in Turkey. Lanham: Lexington Books.

Esen, B., \& Gümüșçü, Ș. (2016). Rising competitive authoritarianism in Turkey. Third World Quarterly, 37(9), 1581-1606.

Ezbawy, Y. A. (2012). The role of the Youth's new protest movements in the January 25th revolution. IDS Bulletin, 43(1), 26-36.

Gökarıksel, B. (2009). Beyond the officially sacred: Religion, secularism, and the body in the production of subjectivity. Social \& Cultural Geography, 10(6), 657-674.

Göksel, O., \& Tekdemir, O. (2018). Questioning the 'immortal state': The Gezi protests and the short-lived human security moment in Turkey. British Journal of Middle Eastern Studies, 45(3), 376-393.

Göle, N. (1996). The forbidden modern: Civilization and veiling. Ann Arbor: University of Michigan Press. Göle, N. (2013). Gezi-anatomy of a public square movement. Insight Turkey, 15(3).

Günay-Erkol, Ç. (2013). Issues of ideology and identity in Turkish literature during the cold war. In C. Örnek \& Ç. Üngör (Eds.), Turkey in the Cold War (pp. 109-129). London: Palgrave Macmillan UK.

Hale, W. (2005). Christian democracy and the AKP: Parallels and contrasts. Turkish Studies, 6(2), 293-310.

Halman, T. (2013). Literature. In M. Heper \& S. Sayari (Eds.), The Routledge handbook of modern Turkey (pp. 76-86). Abingdon-on-Thames: Routledge. 
İzci, İ. (2013). Sokakta hiçbir şey olmamış gibi göstermek şiddettir! Radikal, June 23.

Johnson, C. (2010). The politics of affective citizenship: From Blair to Obama. Citizenship Studies, 14(5), 495-509.

Kadığlu, A. (1998). Cinselliğin İnkarı: Büyük Toplumsal Projelerin Nesnesi Olarak Türk Kadınları [denouncing sexuality: Turkish women as objects of grand social projects]. pp. 89-101 in 75 Yllda Kadinlar ve Erkekler, Bilanço 98, edited by A. B. Hacımirzahoğlu. İstanbul: Tarih Vakfi Yurt Yayınları.

Kandiyoti, D. (1997). Gendering the modern: On missing dimensions in the study of Turkish Modernity. In S. Bozdoğan \& R. Kasaba (Eds.), Rethinking modernity and national identity in Turkey (pp. 113-132). Seattle: University of Washington Press.

Kandiyoti, D. (2001). The politics of gender and the conundrums of citizenship. In S. Joseph \& S. Slyomovics (Eds.), Women and power in the Middle East (pp. 52-61). Philadelphia: University of Pennsylvania Press.

Kaya, A. (2015). Islamisation of Turkey under the AKP rule: Empowering family, faith and charity. South European Society and Politics, 20(1), 47-69.

Konak, N., \& Dönmez, R. Ö. (2015). Deconstructing a neopatrimonial system via humor: Gezi Park 'Capulcu' protests in Turkey. In N. Konak \& R. Ö. Dönmez (Eds.), Waves of social movement mobilizations in the twenty-first century: Challenges to the neo-Liberal world order and democracy. Lanham: Lexington Books.

Korkman, Z. K. (2015). Blessing neoliberalism: Economy, family, and the occult in millennial Turkey. Journal of the Ottoman and Turkish Studies Association, 2(2), 335-357.

Korkman, Z. K., \& Açıksöz, S. C. (2013). Erdogan's masculinity and the language of the Gezi resistance. Jadaliyya, June 22.

Lauenstein, O., Murer, J. S., Boos, M., \& Reicher, S. (2015). 'Oh motherland I pledge to thee ...': A study into nationalism, gender and the representation of an imagined family within National Anthems. Nations and Nationalism, 21(2), 309-329.

Mardin, Ș. (1973). Center-periphery relations: A key to Turkish politics? Daedalus, 102(1), 169-190.

Mayer, T. (1999). Gender ironies of nationalism: Sexing the nation. London; New York: Routledge.

Mercea, D., \& Bastos, M. T. (2016). Being a serial transnational activist. Journal of Computer-Mediated Communication, 21(2), 140-155.

Mostov, J. (1999). Sexing the nation/desexing the body: Politics of national identity in the former Yugoslavia. In T. Mayer (Ed.), Gender ironies of nationalism: sexing the nation (pp. 89-110). London; New York: Routledge.

Önder, S.S. (2013). Interview with Sirrı Süreyya Önder. Demokrat Haber. Retrieved November 7, 2017 (http://www.demokrathaber.org/medya/sirri-sureyya-herkes-engels-okusun-h18999.html).

Özen, H. (2015). An unfinished grassroots populism: The Gezi Park protests in Turkey and their aftermath. South European Society and Politics, 20(4), 533-552.

Parla, A. (2001). The 'honor' of the state: Virginity examinations in Turkey. Feminist Studies, 27(1), 65-88.

Pateman, C. (1988). The sexual contract (1st ed.). Stanford: Stanford University Press.

Șahan, F. (2013). Sivil Darbe Engellendi. Yeni Şafak, June 9.

Sancar, S. (2012). Türk modernleşmesinin cinsiyeti : erkekler devlet, kadinlar aile kurar / Serpil Sancar. 1. bask. Cağaloğlu. İstanbul: İletișim.

Sancar, S. (2016). Erkeklik: İmkansiz Iktidar Ailede, Piyasada ve Sokakta Erkekler. 4th ed. Metis Yayınları.

Schatzberg, M. G. (2001). Political legitimacy in middle Africa: Father, family, food. Bloomington: Indiana University Press.

Sirman, N. (2005). The making of familial citizenship in Turkey. In Citizenship in a global world: European questions and Turkish experiences (pp. 147-172). London; New York: Routledge.

Stewart, A. L., Leach, C. W., Bilali, R., Betül Çelik, A., \& Cidam, A. (2019). Explaining different orientations to the 2013 Gezi Park demonstrations in Istanbul, Turkey. British Journal of Social Psychology Published online Feb., 11, 2019. https://doi.org/10.1111/bjso.12316.

Taş, H. (2017). Street arts of resistance in Tahrir and Gezi. Middle Eastern Studies, 53(5), 802-819.

Thomas, G. (2011). Contesting legitimacy in Chile: Familial ideals, citizenship, and political struggle, 19701990. Penn State Press.

Threadgold, T. (1994). Performing genre: Violence, the making of protected subjects, and the discourses of critical literacy and radical pedagogy. Changing English, 1(1), 2-31.

Tuğal, C. (2013). 'Resistance everywhere': The Gezi revolt in global perspective. New Perspectives on Turkey, $49,157-172$.

Verdery, K. (1994). From parent-state to family patriarchs: Gender and nation in contemporary Eastern Europe. East European Politics and Societies, 8, 225-255.

Volpp, L. (2002). The citizen and the terrorist. Immigration and Nationality Law Review, 23, 561-586. 
Wedeen, L. (2015). Ambiguities of domination: Politics, rhetoric, and symbols in contemporary Syria. Chicago: University of Chicago Press.

White, J. B. (2003). State feminism, modernization, and the Turkish republican woman. NWSA Journal, 15(3), 145-159.

Whitehead, C., \& Bozoğlu, G. (2016). Protest, bodies, and the grounds of memory: Taksim Square as 'heritage site' and the 2013 Gezi protests. Heritage \& Society, 9(2), 111-136.

Yeğenoğlu, Meyda. 1998. Colonial fantasies: Towards a feminist reading of orientalism Cambridge; New York: Cambridge University Press.

Yörük, E., \& Yüksel, M. (2014). Class and politics in Turkey’s Gezi protests. 89, September-October 2014. New Left Review, (89), 103-123.

Young, I. M. (2003). The logic of masculinist protection: Reflections on the current security state. Signs, 29(1), 1-25.

Zacharias, U. (2001). Trial by fire: Gender, power, and citizenship in narratives of the nation. Social Text, 19(4), 29-51.

Publisher's note Springer Nature remains neutral with regard to jurisdictional claims in published maps and institutional affiliations.

Alev Çınar is Professor of Political Science at Bilkent University, Turkey. She received her MA in Sociology from Bogazici University, $\mathrm{PhD}$ in Political Science from the University of Pennsylvania, and she completed two postdoctoral fellowships at the International Center for Advanced Studies, New York University, in the field of Urban Studies, and the Five College Women's Studies Research Center, University of Massachusetts at Amherst in the field of Women's Studies. She has also taught at the University of Massachusetts at Amherst as a Ford Associate and at Bryn Mawr College as a Fulbright Visiting Specialist. Her current research interests include the intellectual foundations of politics; current Islamic political thought in Turkey; political Islam; state, nation, and citizen building; gender and patriarchal statehood; formation of the national subject in relation to ethnicity, gender, religion (Islam), class; nation-building, modernity, secularism, and Islam in Turkey; subject formation; urban space, public culture, and the media as instruments of nation building. She is the author of Modernity, Islam and Secularism in Turkey: Bodies Places and Time (2005); co-editor of Urban Imaginaries: Locating the Modern City (2007), and of Visualizing Secularism and Religion: Egypt, Lebanon, Turkey, India (2012). Her articles have appeared in journals such as Comparative Studies in Society and History; International Journal of Middle East Studies; Theory, Culture and Society; and Signs: Journal of Women in Culture and Society. Çınar has received various awards and grants from a number of institutions, including Fulbright, Ford Foundation, Social Science Research Council, Mellon Foundation, United States Institute of Peace, Institute for Advanced Study membership, Turkish Tubitak Research Grant, a Distinguished Teacher Award from Bilkent University, and the Boğaziçi University, Üstün Ergüder Research Award in Political Science. 